\title{
New normal and health protocol implementation in the farmers
}

\author{
Argyo Demartoto* \\ Department of Sociology, Universitas Sebelas Maret, Surakarta, Central Java, Indonesia
}

\begin{abstract}
Farmer becomes a professional group vulnerable to Covid-19 infection. Despite not doing activities with many people, but the risk of Covid-19 infection is still high in this group. The importance of farming sector sustainability requires farmers to keep healthy to maintain farming productivity. New normal era gives the public an opportunity of working outside home as usual by implementing health protocol. Phenomenon of health protocol implementation by farmers and those related during Covid19 pandemic in Sukoharjo, Indonesia is the object studied in this research using Beck's risk society theory. In this explorative study, in-depth interview, focus group discussion, and observation were conducted on clean and healthy living behavior in implementing health protocol in working during Covid-19 pandemic, and documentation was also conducted. The result indicates an appeal related to health protocol for farming sector and the movement to prevent Covid-19 transmission in the farmers in Sukoharjo. Attempt of implementing health protocol was taken by activating the agricultural extension officer's role in socializing Covid19, new normal, and health protocol to farmer groups in Sukoharjo. During working, the farmers interact rarely with other farmers, wear mask, keep social distance, and wash hand.
\end{abstract}

\section{Introduction}

Farmer is a profession vulnerable to Covid-19 infection. Majority farmers belong to elder over 50-year age category. Although they do farming only in the farm and do not travel to outside town, farmers can be infected with Covid-19. The risk of Covid-19 transmission among farmers remains to be high, despite their social interaction with fellow farmers or farmer partners only. This high risk of virus transmission affects the farming production and distribution process during Covid-19 pandemic. Therefore, farmers and their family should get health protection through the implementation of health protocol [1,2].

The importance of food material production and distribution dependent on farming sector requires the farmers and their family to be in healthy condition [3]. The large number of farmers should be balanced with equivalent health protection along with various focused and massive education and socialization. Farming Human Resource and Education Agency of the Republic of Indonesia's Ministry of Agriculture has instructed the presence of facilitator in the attempt of encouraging farmer productivity by considering health protocol

* Corresponding author: argyodemartoto fisip@staff.uns.ac.id 
such as avoiding the crowd or not assembling with many people, wearing mask, doing social distancing, and washing hand as frequently as possible. Nevertheless, many farmers still have no understanding on the urgency of obeying health protocol during Covid-19 pandemic time. It makes the risk of virus transmission higher among the farmers.

A big change has occurred from early modernity into advanced modernity. In contrast to early modernity in which individuals predicted and planned their future more easily, in advanced modernity instead individuals are faced with bigger risk and uncertainty. In risk society, individuals fight for minimizing the risk to get safety and certainty in their life [4, $5]$.

The spokesperson of Covid-19 Handling Acceleration of Sukoharjo stated that the accumulated number of corona-positive patients as of March 17, 2021 is 5.039 persons. Various mass media have reported many Covid-19 confirmed cases among farmers. In Sukoharjo, Central Java, some Covid-19 positively confirmed farmers have ever been treated in local hospital and undertaken rapid and swab test indicating reactive result. The farmers stated that they have neither travelled outside town nor received guest from outside, and they do their activities in the farm only. Their families also did self-quarantine and undertook rapid retest in the following 14 days. This reality indicates the farmers' vulnerability to Covid-19 infection. It is interesting to study further, particularly in relation to the farmers' clean and healthy life behavior in Sukoharjo, Indonesia.

\section{Method}

This qualitative research with explorative approach took place in Sukoharjo, Central Java, Indonesia [6]. The author conducted observation, in-depth interview, and focus group discussion, thereby obtained primary data in the form of information acquired directly from the farmers and those related in Sukoharjo. They were selected using purposive sampling technique. Meanwhile, relevant documents obtained from social media and those related became secondary data [7]. The author used source and data collecting technique triangulations to validate the data, and then reduced data, displayed data, and drew conclusions [8].

\section{Result and Discussion}

\subsection{Results}

The ever increasing number of Covid-19 cases in Indonesia makes difficult for the people to do usual activities, including working. However, encouraged by the life need to be fulfilled, people eventually decided to keep working amid the high risk of Covid-19 infection. To respond to this, the Republic of Indonesia's Ministry of Health prepared a new normal order, the behavior of doing working activities as usual followed with the implementation of health protocol. the Republic of Indonesia's Ministry of Health has issued health protocol related to prevention and control specifically through the Republic of Indonesia's Ministry of Health's Decree Number HK.01.07/MENKES/382/2020 about Health Protocol for the people in Public Spaces and Facilities in the attempt of Preventing and Controlling Covid-19.

Health protocol, according to the Head of Disease Prevention and Control of Sukoharjo Health Service, is any rules to be obeyed obligatorily by all people, including farmers, thereby can attempt to prevent the Covid-19 transmission amid the obligation of sufficing their life needs. Health protocol consists of Covid-19 prevention and control. Generally, the farmers in Sukoharjo stated that some forms of health protocol to be obeyed are: keeping 
the hand clean, not touching face, applying coughing and sneezing ethics, wearing mask, doing social distancing and self-quarantine, and maintain their health. The regulation applies to all people, particularly those working outside home. The presence of new policy is expected to minimize the spread of Covid-19.

The Chairperson of Farming and Fishery Service of Sukoharjo stated that farming is one of most strongly surviving sectors, despite Covid-19 pandemic. The farmers cannot stop from cultivating their farm, despite government's appeal to all people to stay at home. However, although farmers keep doing activity in the farm as usual, there have been many farmers who keep obeying health protocol. A farmer in Sukoharjo, Central Java, stated that the farmers in their village have applied health protocol, including wearing mask during working and washing hand with soap after working.

The farmers in Sukoharjo know that, the government through Republic of Indonesia's Ministry of Agriculture has prepared protocol for the farmers to keep productive safely. In addition to general protocol like washing hand and maintaining balanced nutrition, the farmers are also recommended to plant and to consume spices products such as wedang uwuh, jahe, and kunir asem (beverages made of any kinds of herbs) to improve body immunity. An agricultural extension officer in Sukoharjo stated that the extension officers play important role in preventing and controlling the spread of Covid-19 in the farmers. There are seven steps to prevent and to control Covid-19 transmission in the rice farmers: washing hand with soap and clean water, not shaking hand, wearing mask, eating nutritious food (rice, fish, vegetable), doing social distancing between farmers, doing physical exercise (cycling and taking enough rest), and optimizing farming tools and machineries.

Health protocol in farming sector is arranged based on the procedure of agribusiness activities. The procedure involves production preparation, production activity, harvest, post-harvest, transportation, and marketing. It is suggested by the Head of Food Plant, Horticulture, and Plantation Division of Farming and Fishery Service of Sukoharjo. The Head of Ngudi Makmur farmer group in Bulu and Marsudi Mulyo farmer group in Polokarto, Sukoharjo explained briefly the procedure. Production preparation consists of cultivating soil/farm by keeping social distancing between farmers, and then washing hand with soap after working. The tools used by farmers in cultivating their farm have been disinfected previously. Production activity involves planting seed, applying fertilizer routinely, weeding, and likewise monitoring and controlling pest. In this stage, the tools used have been sterilized using disinfectant. The farmers are appealed to keep social distancing and wearing mask. The farmers also provide hand-washing-with-soap facilities to keep their hand clean after working.

Harvesting activity is also conducted by applying health protocol, particularly because harvesting process is labor-intensive, so that it is important to keep the distance between farmers. In addition, other health protocols remain to be done, such as sterilizing farming equipments, wearing mask, and washing hand. All equipments are sterilized post-harvesting and are maintained for their cleanliness to be used in the next harvesting process. The process of packaging the farming production output is also conducted cleanly and sterilely. Product transportation is also conducted by considering the safety and the cleanliness for the farmers doing it. The product transported has been ensured for its cleanliness and safety to be marketed. The marketing of farming product is conducted by maintain safe distance between sellers and between sellers and buyers. The farmers marketing their product are appeal to wear mask and gloves, and to wash hand before and after doing transaction.

The Head of Farming and Fishery Service of Sukoharjo stated that International Labor Organization (ILO) prepared guidelines of occupational safety for farmers, Safety and Health in Agriculture, ILO codes of practice. This guideline is important to maintain occupational safety and health to control the work risk in farming sector in order to prevent accident and disease in the farmers. This ILO's guideline has considered the importance of 
gender equality in female and male farmers. Farmer is one of professions vulnerable to Covid-19 because most farmers belong to elder category. Farmers also assume various risks particularly in using farming tools or machineries and negative effect of farming chemicals. Therefore, the farmers should be protected and given education or socialization related to health protocol in doing farming production.

Occupational safety and health system emphasizes on the importance of awareness in all parties, in this case the farmers. The provision of Self Protecting Equipments (SPE) is important to be realized to minimize the risk in farming sector, including farm cultivation, harvesting activity, and farming product marketing. SPE can be helmet or head protector, face protector, eyes protector, gloves, respiratory protector, and ear protector. Health protocol facilities such as clean water and soap for hand washing are provided in adequate quantity and accessible to the farmers in Sukoharjo.

\subsection{Discussion}

The appearance of Covid-19 within modern society is the manifestation of unexpected technology advance that cannot be ascertained for its occurrence but results in big consequence. This pandemic proves that modern society lives adjacently to various risks [5]. Based on Beck's risk society theory, the existence of Covid-19 pandemic will not vanish immediately due to the people's ignorance and egoism related to the regulation. In addition, Beck stated that the longer the risk society survives in modernity, the more is the new character grows, that is, individuals will have adaptive and anticipative behavior to avoid the risk threat, thereby called reflective society [9].

Adapting and anticipating measures taken by modern society in Indonesia during Covid-19 pandemic are, among others, to appear new normal era and to apply health protocol application [10]. The more the number of Covid-19 positive cases, the bigger is the risk to be faced by both urban and rural communities. The risk then expands and thereby results in imbalance in various sectors, particularly social and economic. Economic issue, particularly food, becomes the society's priority to be maintained. The basic source of food product production is farming sector; thus, the anticipating measure taken by risk society to maintain the productivity of farming sector is to give the farmers the health protection $[11,12]$.

Preventing the advent of risk over something is an important action to take compared with coping with the risk left to occur without anticipation. It is important to take in suppressing the Covid-19 transmission rate, particularly in farming sector. WHO establishes some measures to safeguard farmers particularly from Covid-19 transmission. Health protocol also applies to farmers, including washing hand regularly, particularly after working in the farm. The importance of providing washing-hand-with-soap facilities in workplace environment, keeping at least $1-\mathrm{m}$ distance between farmers during working on the farm, avoiding touching eyes, nose, and mouth because hand is the body part most actively touching many surfaces and bringing many bacteria, wearing mask during working in the farm, and when feeling unhealthy, the farmers are appealed to stay at home and to call medical assistance when their condition worsens. Farmers need agricultural extension officer to inform new development related to Covid-19 and to socialize the health protocol to them $[2,13]$.

Covid-19 pandemic today represents the importance of breaking the virus transmission chain, particularly to the population vulnerable to virus infection such as farmers [14]. The prevention of pandemic transmission can be done both individually by maintaining self cleanliness through washing hand as frequently as possible and in group by keeping social distancing and avoiding crowd when doing activities outside home. 


\section{Conclusion}

New normal era is one of adapting strategies taken by risk society in Indonesia. Modern society living adjacently to various consequences should adapt to and to anticipate the appearance of next risk, one of which is through applying health protocol. To respond to various problems arising, particularly economic and food availability problems, health protocol is also prepared specifically for farming sector. Although the farmers' job is generally to cultivate the farm, the risk of Covid-19 transmission remains to be high. Farming sector remains to be the main priority to be maintained by the state to keep operating, despite pandemic situation. The farmers' health condition is important to be maintained in order to break the virus transmission chain and to maintain the productivity of farming sector.

\section{References}

1. I. Darnhofer. Farm resilience in the face of the unexpected: lessons from the Covid-19 pandemic. Agr Hum Val, 37 (2020).

2. A.D. Laksono, R. D. Wulandari, M. Ibad, Y.T. Herwanto, K.P. Sarweni, R.A.P. Geno, E. Nuraheni. Predictors of Healthy Lifestyle in the COVID-19 Pandemic Period in East Java, Indonesia. Journal of Critical Review.7, 18, 1515-1521. (2020)

3. Y. Zhao, C. Cui, K. Zhang, J. Liu, J. Xu, E. Nisenbaum, Y. Huang, G. Qin, B. Chen, M. Hoffer, S.H. Blanton,F. Telischi, J.M. Hare, S. Daunert, B. Shukla, S.G. Pahwa, D.T. Jayaweera, P.E. Farmer, C. del Rio, X. Liu, Y. Shu. Covid-19: A Systematic Approach to Early Identification and Healthcare Worker Protection. Front. Public Health. 8, 205, 1-8. (2020)

4. U. Beck, Risk Society: Towards a New Modernity (Sage Publication Ltd, London, 1992)

5. F. Mansouri, F, Sefidgarbaei. Risk society and Covid-19. Can J Community Ment Health. 112, 36-37. (2021)

6. R.A. Stebbins. Exploratory Research in the Social Sciences (Sage Publication Inc, Thousand Oaks, California, 2001)

7. R.A. Krueger, M.A. Casey. Focus Groups A Practical Guide for Applied Research $5^{\text {th }}$ Edition (Sage Publication Inc, Thousand Oaks California, 2015).

8. B.M. Miles, A.M. Huberman, J. Saldana. Qualitative Data Analysis: A Methods Sourcebook $3^{\text {rd }}$ Edition(Sage Publication Inc, Thousand Oaks, California, 2014)

9. K.G. Nygren, A. Olofsson. Managing the Covid-19 pandemic through individual responsibility: the consequences of a world risk society and enhanced ethopolitics. J Risk Res.23, 7-8, 1031-1035. (2020)

10. S, Riyanto, I.P. Asturiningtyas, I. Setianingsih, N. Nur'aini, Z. Zainuddin, S. Purwoko, A. Prihatin, A. Mirzautika. Healthy lifestyles during the COVID-19 new normal era in Indonesia. Ann Trop Med Publ Health. 24, 1. (2021)

11. S. Marwanti, E. Antriyandarti. The Effect of Anxiety on Farmers' Compliance in Implementing Covid-19. Preventive Health Protocol in Daily Life: A Case Study in Rural Java. De Clínica Psicológica. 29, 743-752. (2020)

12. N. Paganini, K. Adinata, N. Buthelezi, D. Harris, S. Lemke, A. Luis, J. Koppelin, A. Karriem, F. Ncube, E. N. Aguirre, T. Ramba, I. Raimundo, N. Sulejmanovi, H. Swanby, D. Tevera, S. Stöber. Growing and Eating Food during the COVID-19 Pandemic: Farmers' Perspectives on Local Food System Resilience to Shocks in 
Southern Africa and Indonesia. Sustainability. 12, 1, 1-26. (2020)

13. B. Yanti, E. Mulyadi, Wahiduddin, R.G.H. Novika, Y.M.D. Arina, N.S. Martani, N. Nawan. Community Knowledge, Attitudes, and Behavior Towards Social Distancing Policy As A Means Of Preventing Transmission Of Covid-19 In Indonesia. Jurnal Administrasi Kesehatan Indonesia. 8, 1, 4-14. (2020)

14. A. K. Sadati, M.H.B. Lankarani, K.B. Lankarani. Risk Society, Global Vulnerability and Fragile Resilience; Sociological View on the Coronavirus Outbreak. Shiraz EMedical Journal.21, 4. (2020) 